\title{
Climate change and disasters: analysis of the Brazilian regional inequality
}

Mudanças climáticas e desastres: análise da desigualdade
regional brasileira

Letícia Palazzi Perez ${ }^{\mathrm{a}}$

Saulo Rodrigues-Filhob

José Antônio Marengoc

Diogo V. Santos ${ }^{d}$

Lucas Mikosz

${ }^{a}$ Visiting professor at the Federal University of Paraiba Department of Architecture and Urbanism, João Pessoa, PB, Brasil E-mail: leticia.palazzi@gmail.com

${ }^{b}$ Professor at the University of Brasilia, Sustainable Development Center Brasília, DF, Brazil E-mail: srodrigues@unb.br

${ }^{c}$ Head of Research and General R\&D Coordinator at the Center for Monitoring and Early Warnings of Natural Disasters, Cemaden,

São José dos Campos, SP, Brazil E-mail: jose.marengo@cemaden.gov.br

${ }^{d}$ Vulnerability and Adaptation Supervisor in the scope of the Fourth Communication of Brazil to the Convention of Climate Change Ministry of Science, Technology and Innovations, MCTI, Brasilia, DF, Brazil E-mail: diogo.santos@mctic.gov.br

e Infrastructure analyst at Cenad, Ministry of Regional Development, Brasilia, DF, Brazil

E-mail: lucas.mikosz@gmail.com

Data and results presented in this article were developed under the project of the "Fourth National Communication and Biennial Update Reports of Brazil to the Climate Convention", coordinated by the Ministry of Science, Technology and Innovations, with the support of the United Nations Development Programme and resources of the Global Environment Facility, to which we offer our thanks. 


\section{ABSTRACT}

One of the main consequences of climate change in Brazil is the increase in the occurrence of extreme rainfall, which in turn trigger Hydrometeorological disasters; the Brazilian continental dimension, the regional characteristics of biomes and socioeconomic inequality are conditioning factors for the impacts of extreme events in the country. This work analyzes Brazil's socioeconomic and urban infrastructure vulnerability, combined with the regional exposure of the population, based on disasters observed and future scenarios for the occurrence of rainfall extremes. As a result, it points out that climate change impact differently on large Brazilian regions, due to population density and the poor quality of urban infrastructure services.

Keywords: Disasters Climate. Change Social. Inequality. Urban Infrastructure.

\section{RESUMO}

Uma das principais consequências das mudanças climáticas no Brasil é o aumento dos extremos de chuva, que causa desastres hidrometeorológicos. A dimensão continental brasileira, as características regionais dos biomas e a desigualdade socioeconômica são fatores condicionantes dos impactos dos eventos extremos no País. Este trabalho analisa a vulnerabilidade socioeconômica e de infraestrutura urbana brasileira, aliada à exposição da população, de maneira regional, a partir de desastres já observados e dos cenários futuros para a ocorrência de extremos chuvosos. Como resultados, aponta que as mudanças climáticas impactam diferentemente as grandes regiões brasileiras, em função da densidade populacional e da baixa qualidade dos serviços de infraestrutura urbana.

Palavras-chave: Desastres. Mudanças Climáticas. Desigualdade Social. Infraestrutura Urbana.

\section{INTRODUCTION}

One of the consequences of climate change is the variation in the rainfall regime and an increase in the frequency and intensity of extreme weather events (IPCC, 2014; PBMC, 2014; MARENGO, 2010). Extreme climate events like rains, droughts or heat waves, are characterized by occurring with intensity, duration or season that is different from the average climate state (MARENGO, 2009), and are natural phenomena that trigger disasters when they bring impacts to society (TOMINAGA et al., 2009).

Highly-intense short-duration extreme rainfall causes floods; mildly-intense long-duration extreme rainfall soaks the soil; therefore, the subsequent occurrence of short-duration highly-intense rain when the soils is waterlogged causes landslides (TOMINAGA et al., 2009), also affecting the health of the population, as they cause deaths, leave people injured, unsheltered, and increase the risk of contamination by waterborne diseases (HACON et al., 2018).

For example, heat waves are associated to an increase in stress and sunstroke rates, aggravation of cardiovascular diseases, (HACON et al., 2018; PBMC, 2014), and insufficient rainfall determines normal dry periods, but when such periods are extended and intensified by the increase in temperature, they are characterized as droughts (TOMINAGA et al., 2009; MARENGO et al 2019; 2020).

Specifically, related to hydrometeorological disasters, triggered by extreme rainfall, according to the EM-DAT (the database of the Centre for Research on the Epidemiology of Disasters (CRED), between 1980 and 2000, 1,828 worldwide flood-type or landslide-type events were recorded, jumping to 3,550 worldwide occurrences between 2001 and 2019. The impact of extreme rainfall events does not affect everyone in the same way. EM-DAT data presented in the United Nations report on poverty and losses caused by disasters (UNISDR, 2018) show that between 1998 and 2017 an average of 130 people per million died in disasters in poor countries, while this average falls to 18 in rich countries. 
Another important fact is that according to the 2019 report by the United Nations Disaster Risk Reduction (UNDRR, 2019), more than $50 \%$ of the world population lives in urban areas, and by 2050 this percentage should increase to $75 \%$. It is precisely in cities where the population most affected by extreme weather events are concentrated.

In cities, rainwater drainage systems have been used for centuries for different purposes, among which flood containment (BURIAN \& EDWARDS, 2002). Tucci (2008) and Kita (2017) point to environmental sanitation as an essential element of urban infrastructure, and Tucci (2008) states that the occupation of lowland or slopes areas, and soil waterproofing without sufficient drainage to capture rainwater, trigger the processes of floods, in addition to landslides.

Brazil has a historic presence of informal settlements, without urban infrastructure (MARICATO, 2009), with socio-spatially segregated cities, and it is precisely in areas of low or no urban infrastructure that the poorest, and most economically vulnerable population, lives (MARICATO, 2003 a and b; 2009), which makes Brazilian cities even more vulnerable to climate change.

A reduction of disaster risks in Brazil includes monitoring and issuing alerts, which is an attribution of the CEMADEN; disaster risk management, an attribution of the National Center for Risk and Disaster Management (CENAD), as well national, state and municipal Civil Defense and the Geological Survey of Brazil, working with CEMADEN and Brazilian Institute of Geography and Statistics (IBGE). It also includes the policy for housing provision ${ }^{1}$ and the development of instruments for planning urban development and managing risk areas.

It is understood that, in addition to the population's socioeconomic vulnerabilities, urban policy is a determining factor for climate adaptation. Hence, this article presents a discussion on natural disasters in Brazil, in the context of climate change and social inequality and urban infrastructure. This work analyzes the relationship between natural disasters and urban infrastructure, as well as Brazil's regional socioeconomic conditions, taking into account future scenarios for the occurrence of rainfall extremes. The objective is to understand which Brazilian regions, socioeconomic and environmental conditions are more vulnerable to Hydrometeorological disasters.

\subsection{HYDROMETEOROLOGICAL DISASTERS IN BRAZIL}

Hydrometeorological disasters have been identified in a number of metropolitan regions, including the metropolitan region of São Paulo (MARENGO et al., $2020 \mathrm{a}$ b), and urban precariousness aggravates the impacts of extreme rainfall events (MARICATO, 2009; HUMMELL, 2016; RASCH, 2016; TRAVASSOS et al., 2020). Changes in the rainfall regime and increase in the occurrence of extreme rain have already been identified in the Southern and Southeastern regions of Brazil in the past 50 years (DUNN et al., 2020; MARENGO, 2007), but small and medium-sized cities in the interior also concentrate areas of risk and are subject to disasters (SAITO et al., 2019 e 2020).

In fact, disasters with the highest death tolls in Brazil are landslides, followed by floods. The Brazilian Atlas of Natural Disasters (CEPED 2020) shows that between 2000 and 2019, totaling only 27\% of the total occurrences of all typologies of disasters, and affecting $20 \%$ of the total people affected, the hydrometeorological disasters accounted for $84 \%$ of the unsheltered in the country, and $79.6 \%$ of the deaths: 3.040 out of the 3.816 deaths in the period.

Brazil's continental dimensions imply different levels of exposure to the impacts of the climate change in its territory. In Northern Brazil, represented by the Amazon biome, there are indications of changes in rainfall regime that may cause from sudden floods to droughts, which may become seasonal (MARENGO and ESPINOZA, 2016, MARENGO et al., 2018; PBMC, 2014).

1 | Sustainable Development Goal, SDG 13, Indicator 13.1.1 Available: https://odsbrasil.gov.br/objetivo13/indicador1312 
In the Brazilian Center-West region, basically composed of the Cerrado and the Pantanal, and in the Northeast, covered by the Caatinga, the data analyzed by the PBMC (2014) point to an increase in temperature between 5 to $20 \%$ by 2040 , further aggravated in the future, mainly in the Caatinga, where in addition to the trend of more recurrent severe droughts, an increase in floods due to intense and short-term rains is also expected. In the Southeastern region, the PBMC (2014) indicates that minimum temperatures should increase, despite the gradual increase in temperatures in general, and an increase in rain extremes of 5 to 10\% in 2040 and up to 30\% by 2100 (IPCC 2014, CHOU ET AL 2014 $a$ and b). In Southern Brazil, PBMC (2014) models indicate a similar situation to the Southeast, with a gradual increase in temperature, 15 to $20 \%$ increase in rainfall by 2040, reaching a $40 \%$ increase in 2100. This increase would be in the form of intense events of extreme rainfall with dry and warm periods in-between.

An increase in rainfall extremes may intensify the occurrence of hydrometeorological disasters, mainly in exposed urban areas (MARENGO, 2007, DEBORTOLI et al 2016; AVALA et al, 2019); and the increase in temperature, combined with population growth and urban sprawl over the Atlantic Forest, may intensify water scarcity and increase the risk of rising sea levels in coastal areas (PMBC, 2016, 2017).

In 2011, Brazil's worst natural disaster happened in the mountainous region of Rio de Janeiro, with 947 people killed, over 300 missing and thousands displaced, besides severe economic losses and the destruction of housing and infrastructure due to floods and landslides (MARENGO and ALVES, 2012; GRAEFF et al., 2012).

In January 2020, Belo Horizonte (capital of the state of Minas Gerais) and other 195 cities in the state were hit by the highest recorded rainfall in 110 years. Cities declared a state of emergency, with 60 people dead and almost 30 thousand displaced (UFMG, 2020). On 3 February 2020, in the Baixada Santista region, in the state of São Paulo, a single extreme rainfall event caused 45 deaths and left over 200 families unsheltered (GOVERNMENT OF THE STATE OF SÃO PAULO, 2020). Floods in the state of Amazonas, in 2009 and 2012 (MARENGO et al., 2013), affected some 20,000 families who lived in precarious settlements.

It is worth highlighting the focus on Brazilian urban areas, where there has been a significant increase in the number of disasters, as shown in Figure 1, which shows the population affected by disasters by type of household: rural $x$ urban.

Disaster registers and increase on population

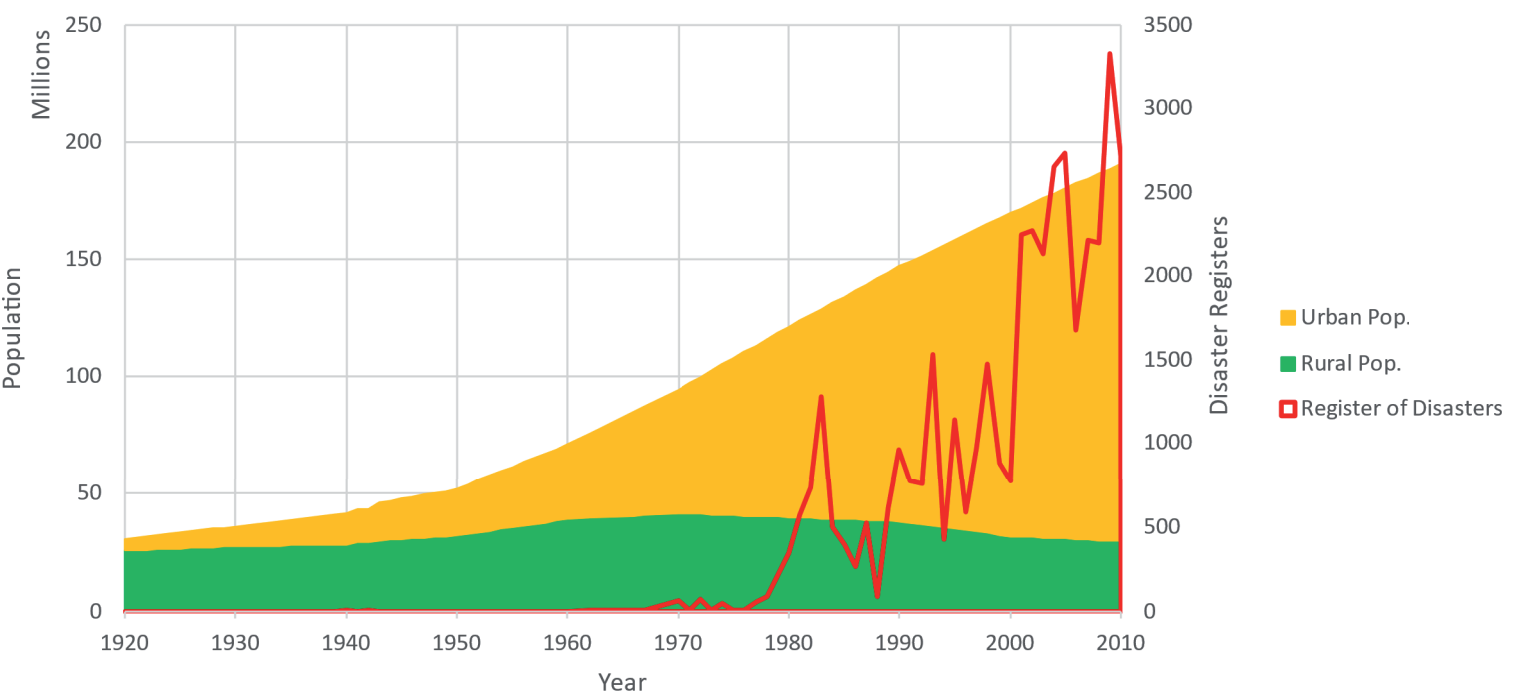

Figure 1 | Disasters in Urban x Rural Brazil 
Given the Brazilian urban precariousness, the increase in rainfall extremes is expected to increasingly intense disasters (TRAVASSOS et al., 2020; RASCH, 2016; MARENGO, 2007).

\subsection{SOCIO-SPATIAL INEQUALITY AND HYDROMETEOROLOGICAL DISASTERS IN BRAZIL}

Climate change impacts on human life are complex and may be enhanced or minimized according to individual and collective determinants that are inherent to a given social organization and their interrelations, including aspects such as age, health system's capacity, and e conditioning social factors (HUMMELL, 2016; RASCH, 2016; RUFAT et al., 2015; KOKS et al., 2015).

With regard to social conditions, the housing situation, sanitation, personal hygiene and access to health services are factors that influence the vulnerability of populations exposed to climate stress, which when combined to other environmental exposures may act as a trade-off, generating even more risk for populations (HACON et al., 2018; HUMMELL, 2016; RUFAT et al., 2015).

Brazil is an unequal and socio-economically vulnerable country. The urgency of the issue on natural disasters in Brazil becomes even more evident when the effects of the profound social inequality (OXFAM, 2019; IPEA, 2017) are observed, affecting the ability of a large share of the population to cope with impacts, whether health or climate ones (IPCC, 2014), due to their lack of access to appropriate housing and sanitation conditions, for example.

According to Figure 2, the Fifth Assessment Report of the Intergovernmental Panel on Climate Change (IPCC, 2014) points out that the most socially vulnerable populations are also the most vulnerable to climate change impacts. Inequality identity aspects and dimensions, expressed by social class, gender, ethnicity, skin color, age and special needs are conditioning factors of multidimensional vulnerability and risk exposure.

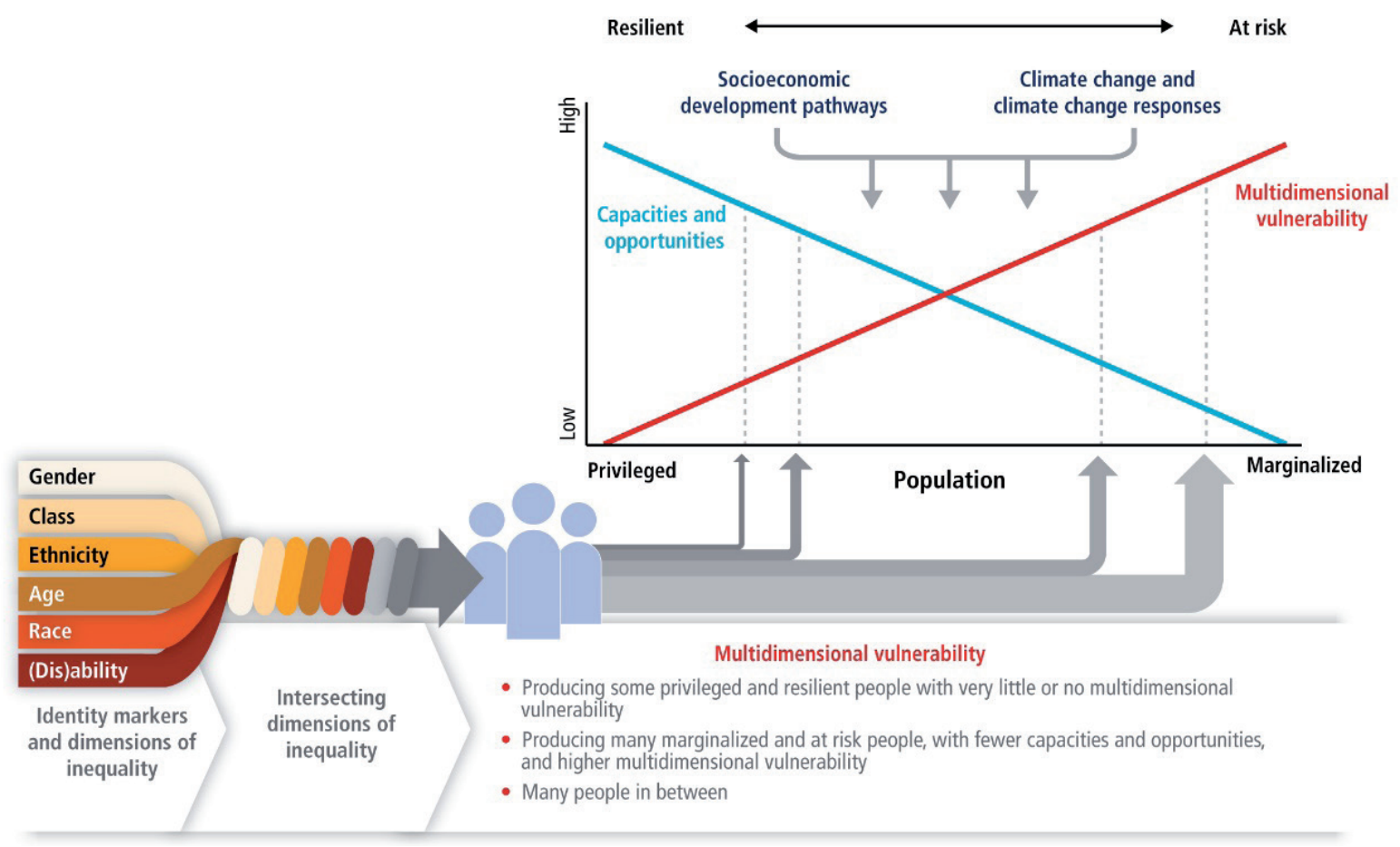

Figure 2 | Vulnerability multidimensions.

Source: AR5 (IPCC, 2014) WGII, Cap. 13, Fig. 13.5 (translated by the authors).

Dias et al. (2018) explains the relationship between socioeconomics, urban infrastructure conditions and the occupation of at-risk areas, from the crossing of census information, including the location of 
subnormal agglomerates ${ }^{2}$ (AGSN, in the Portuguese acronym) and the quality of urban infrastructure, showing that not only AGSN have low urban infrastructure rates, such as access to piped water and sewage, but this is a condition that also occurs in formally regularized Brazilian settlements.

Some $85 \%$ of the Brazilian population live in cities, almost $25 \%$ live in the country's main metropolitan regions, and most Brazilian cities lack basic environmental sanitation and urban drainage services (IBGE, 2010; 2017). According to the Ministry of Cities (2007) and the João Pinheiro Foundation (MARICATO, 2009), there are approximately 12 million informal and precarious households in Brazil, but according to IBGE (2010), only 3 million households are considered AGSN, where almost 13 million people live.

Of the 5,570 Brazilian municipalities, $75 \%$ are exempt from preparing an Urban Master Plan because they have less than 20 thousand inhabitants, and unplanned urbanization leads to informal settlements, with no environmental licensing, nor proper regulation of land subdivision and, although $70 \%$ of AGSN are found in and around capitals (IBGE, 2010), informality and precariousness are increasing in small and medium-sized cities (PEREZ et al., 2017).

The Brazilian urbanization process, according to Maricato (2000), "is a slum production mechanism" and, 20 years after this statement, even with the approval of the City Statute (LF 10.257/2001), Brazilian cities are still presenting high socioeconomic and environmental inequality, with enclaves of poverty and slums (CALDEIRA, 2010; MARICATO, 2017; 2009; 2003 a and b). For decades, private ownership of land, derived from colonial times, associated with formal housing for the upper classes of the population, has created socio-spatial segregation, and part of the low-income population started to occupy borders of streams, floodplains, lands of high declivity, especially in large cities, informality and precariousness are what is left for the low income classes (MARICATO, 2009), which, in addition to their financial condition, now see their houses as another factor of vulnerability against hydrometeorological disasters (HARDOY AND PANDIELLA, 2009). This is reflected in the fact that $42 \%$ of AGSNs are in at-risk areas mapped by IBGE-BATER (IBGE, 2017).

Saito et al. (2020) conducted an extensive analysis of the IBGE-BATER risk areas with census data, showing that more than 8 million Brazilians are living in risk areas, concentrated in 825 municipalities, $47.7 \%$ of which are small cities, with up to 100 thousand inhabitants, $29.6 \%$ in cities with up to 500 thousand inhabitants and $22.7 \%$ in large urban centers. In absolute numbers, the population living in risk areas goes against the trend: $48 \%$ in large cities, $28 \%$ in cities with up to 500 thousand inhabitants and $24 \%$ in small cities with up to 100 thousand inhabitants, but the authors consider that, in relative numbers, residents in small Brazilian cities are more exposed to risk, compared to $8 \%$ of inhabitants in large cities (SAITO et al., 2020).

According to Saito et al. (2019), $67 \%$ of households in risk areas in the Northern region, $54 \%$ in the CenterWest region, $33 \%$ in the Northeastern region, $18 \%$ in the Southern region and $16 \%$ in the Southeastern region do not have adequate sanitation. If, on one hand, urban precariousness is not exclusive to AGSN or large cities, on the other hand, more densely occupied areas, such as the Southeastern region, concentrate more people exposed to hydrometeorological disasters (CEMADEN, 2017).

Territories' climate and physical modeling are not enough to assess the population's vulnerability to disasters. It is necessary to have information that present the spatial heterogeneity of the population's socioeconomic vulnerability (KOKS et al., 2015; HUMMELL et al, 2016).

Several indexes measure and spatialize the inequality of Brazilian municipalities, such as the Social Vulnerability Index (IPEA, 2015) or the MHDI (UNDP, 2013), all of which are based on census data, income, education, urban infrastructure services and sanitation, life expectancy, among other socioeconomic variables. As per Burian \& Edwards (2012), Tucci (2008), Maricato (2009) and Kita (2017), sanitation

2 | Subnormal Agglomerates are a form of irregular occupation of public or private land for housing purposes, in urban or precariously urbanized areas. 
infrastructure and water and sewage networks are essential elements of urban resilience against hydrometeorological disasters. Therefore this article decided not to use a ready-made index, but to build a new one, using raw census data on sanitation, income and household inadequacy ${ }^{3}$ to spatialize these variables within the national territory. The access ranking to health services and basic public education and, subsequently, population density were added to these data. The result was analyzed together with the disasters observed and also discussed in relation to future climate scenarios.

\section{METHODOLOGY}

Alphanumeric data (IBGE, 2010; IDSUS, 2010 and IDEB, 2011) were spatialized by municipality; disaster data observed between 2005 e $2015^{4}$ were plotted in the municipality centroid in which they occurred; future climate scenarios were produced by Chou et al. (2014) and Debortoli et al. (2017), and plotted by this article's authors.

The Urban Vulnerability Index (UVI) was prepared based on Burian \& Edwards (2012), Tucci (2008), Maricato (2009) and Kita (2017), and the variables that make up the UVI were inspired by the SVI' "Urban Infrastructure Dimension" (IPEA, 2015), aimed at characterizing not only the precariousness of urban infrastructure, but also the social conditions that show socioeconomic inequality in Brazil. Also, census data in addition to covering the entire national territory, are compatible with the observed disaster data, which occurred at most 5 years before or after the collection of the 2010 Census.

The following data were considered for the composition of the UVI: IBGE, 2010 (people by permanent private housing units in the municipality; number of permanent private housing units in the municipality; average household income in the municipality; permanent private housing units connected to water and sewage network with garbage collection system in the municipality; number of inadequate or semiinadequate private households in the municipality); quality index of health services in the municipality (IDSUS 2010); quality index of public education in the municipality (IDEB, elaborated in odd years, 2011).

These data have been spatialized and normalized according to the maximums and minimums of the entire base of 5570 municipalities. The following formula was adopted for the calculation of the UVI:

$$
U V I=\text { household density }+ \text { water }+ \text { sewage }+ \text { garbage }+ \text { income }+ \text { adequacy }+ \text { IDEB }+ \text { IDSUS }
$$

Therefore, in order to compose the analysis with the urban vulnerability index, exposure was calculated based on population density as follows:

$$
\operatorname{Exp}=\frac{\ln }{\ln _{10}\left(\text { value }(p d)-\ln _{10}(\text { minimum } p d)\right.}
$$

Where $\mathrm{dp}=$ population divided by area

After exposure calculation, the factor was applied to UVI, creating the Urban Vulnerability Index with population exposure (UVlexp):

$$
\text { UVlexp }=\text { UVI * population density }
$$

\footnotetext{
3 | Inadequate households are the ones with no access to environmental sanitation services and more than two residents per bedroom; Semi-Inadequate households are the ones that present a deficit in only one of the indicators above.

4 | Within CENAD's extensive database, there are inconsistencies that can lead to error. This temporal snapshot had these inconsistencies corrected, such as "flash floods". In the Southern and Southeastern regions, debris flow disasters like the one in the mountainous region of Rio de Janeiro, in 2011, were originally classified as flash floods, while in the Northern region this term is often used for rapid flooding.
} 
Disaster data observed herein were sourced by CENAD, assessed by Mikosz (2017), and grouped in two typologies: (i) landslides and (ii) floods.

Extreme climate indexes were used by the IPCC (2014) and include: RX1day - maximum rainfall in one day; Rx5day - 5-day maximum accumulated rainfall; R95p - accumulated rainfall higher than $95 \%$ of very rainy days; and CWD - maximum consecutive rainy days (any rainfall greater than $1 \mathrm{~mm}$ ). These indexes were used by Debortoli et. al (2017) in studies assessing present and future vulnerability to natural disasters (2017) $)^{5}$. Indexes were generated from outputs of the global HadGEM2-ES MIROC5 models downscaled by the regional Eta model (CHOU et. al., 2014), for the baseline period encompassing 1961-1990 and future RCP 8.5 scenarios for 2010/2040, 2041/2070 and 2017/2099 - which correspond, approximately, to the average global warming levels of $1.5^{\circ} \mathrm{C}, 2^{\circ} \mathrm{C}$ and $4^{\circ} \mathrm{C}$.

\section{RESULTS AND DISCUSSION}

Figure 3 shows disasters related to floods on the left, and landslides on the right. Between 2005 and 2015, 10,225 floods or landslides were reported, affecting over 5 million Brazilians and causing 2,609 deaths.
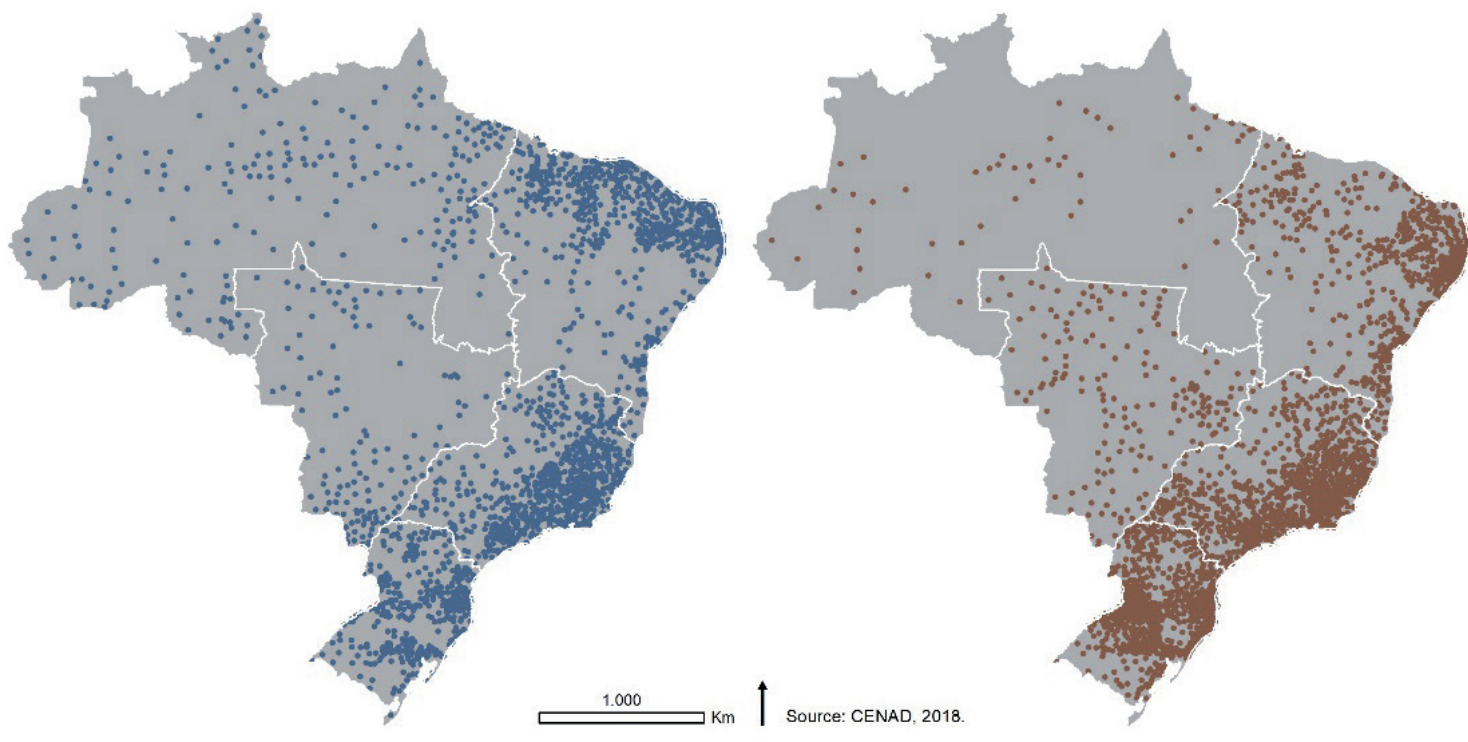

Figure 3 | Disaster spatialization

Source: CENAD (2018). Prepared by Perez, 2020, for QNC Brazil UNFCCC.

UVI (left) and UVlexp (right) were elaborated in order to discuss the disasters observed between 2005 and 2015 (Figure 4). The UVI is composed by sanitation data (water and sewage network, garbage collection), household inadequacy ${ }^{6}$, income in minimum wages, access to health services and public education quality. The UVIexp is the UVI multiplied by the demographic density, which represents population's exposure.

Knowing the different regional Brazilian realities, it was expected that the UVI would show higher especially those furthest from the state capitals, and less vulnerability in the Southern and Southeastern regions.

5 | For a detailed description of each compound indicator: Debortoli et al. (2017) | DOI 10.1007/s11069-016-2705-2.

6 | Vulnerability hotspots to natural disasters: high population concentration areas where natural disasters occur, and which will continue to suffer the impacts of the climate changes that trigger disasters. 
The most recent data on Brazilian households still show this regional inequality in the country. According to the National Household Sample Survey (IBGE, 2017), results of access to sanitary sewage and water network are, respectively: $20 \%$ and $59 \%$ in the Northern region, $45 \%$ and $80 \%$ in the Northeastern region, $53 \%$ and $87 \%$ in the Center-West region, $66 \%$ and $88 \%$ in the Southern region, $89 \%$ and $92 \%$ in the Southeastern. In relation to income (PNAD, 2018), in the Southern and Southeastern regions, the average is around 1 minimum wage; in the Center-West region, it is 0.99 minimum wage, which is at least $40 \%$ higher than in the Northern region (0,65 minimum wage) or the Northeastern region (0,56 minimum wage).
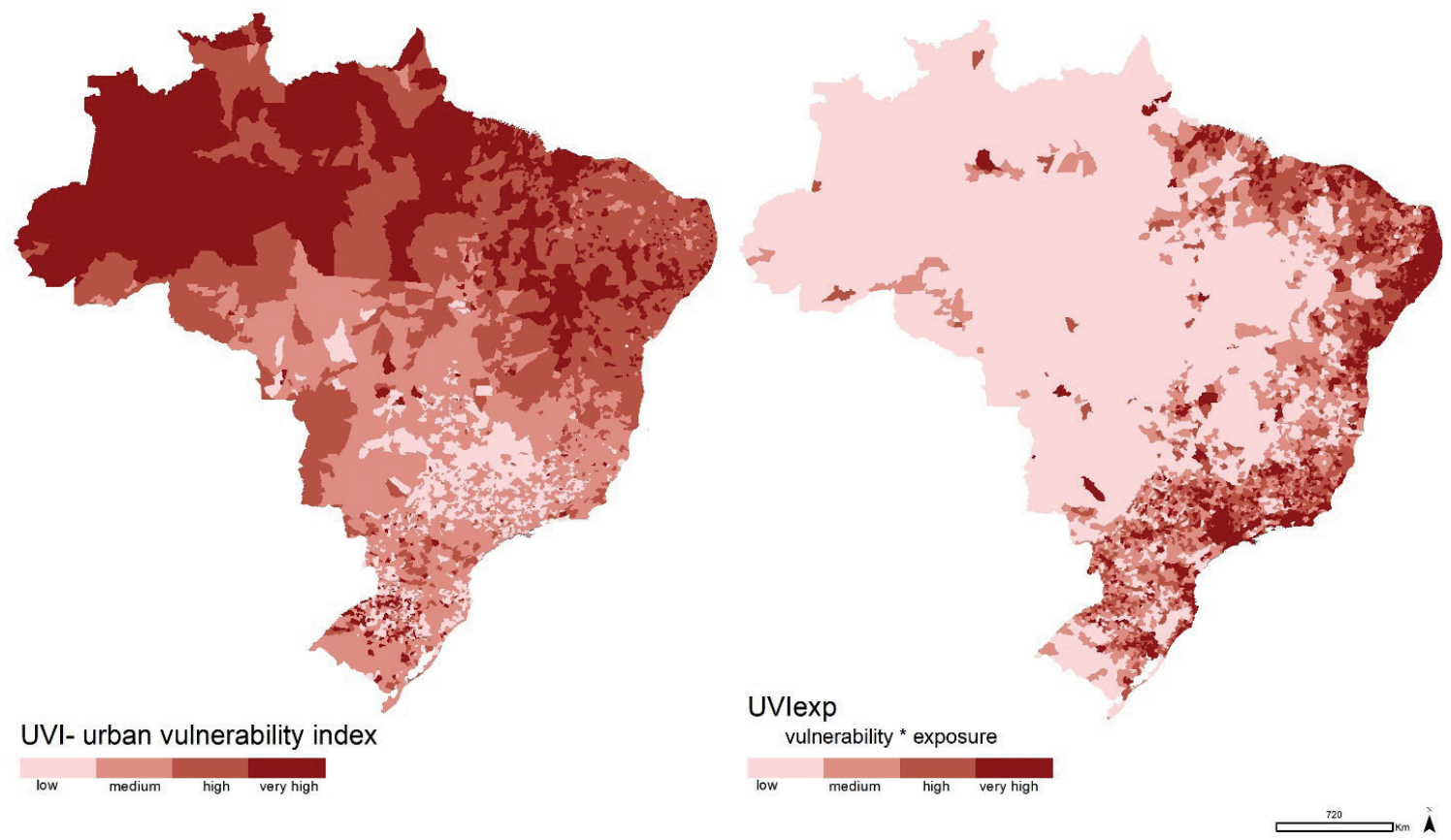

Figure 4 | UVI (left) and UVlexp (right) Source: IBGE and IDSUS (2010) and IDEB (2011) 2010. Prepared by Perez, 2020, for QNC Brazil UNFCCC.

If compared with SVI (IPEA, 2015) or with MHDI (UNDP, 2013), the UVI (Figure 4, left) would present a very similar spatial distribution of vulnerability to the IVS or the MHDI. Other authors, such as Debortoli et al. (2017) and Humell et al. (2016) present socioeconomic vulnerability with the same spatial distribution, based on income, education, access to employment, skin color, among other variables. Similar regional results are due to the fact that the Northern and Northeastern regions are poorer, in terms of income, infrastructure, and access to health services. The Northern region is less densely occupied than the Center-West region, and mainly, than the Southeastern and Southern regions (HUMMELL et al., 2016).

Municipalities in the Northern and Northeastern regions are more vulnerable in several socioeconomic and environmental aspects, which affects mainly the response capacity of these populations and decreases their resilience, but disasters in the proportions of that in the mountainous region of Rio de Janeiro, in 2011 (MARENGO E ALVES, 2012; GRAEFF et al., 2012), had such an impact precisely because it occurred in a densely occupied region.

It is important to highlight that $45 \%$ of municipalities with over 250 thousand inhabitants are in the coastal zone -13 out of the 27 capital cities border the Atlantic Ocean. $40 \%$ of the Brazilian population live in the Southeastern region. On the other hand, there are fewer inhabitants in the entire Northern region compared to the Metropolitan region of the state of São Paulo alone (IBGE, 2010), which, despite having a higher average income than other regions, also presents a high concentration of precarious settlements.

The UVlexp (Figure 4, right) shows the Brazilian urban vulnerability taking into consideration population density, making it possible to visually observe that even though Brazilian cities present a similar 
regional distribution of the economic, educational and environmental vulnerability in the UVI, with similar results to those from Hummell (2016) or Debortoli (2017), it is possible to read this vulnerability associated with the number of people exposed to risk, in the UVlexp. Also, just like Hummell et al vulnerability risk (2016), UVlexp (Figure 4, on the right) also highlights high vulnerabilities in the capital cities: in the Northern region, in addition to the capital cities, large urban centers may be mentioned, such as Santarém - PA, Parintins and Tabatinga - AM or Cruzeiro do Sul - AC; in the Center-West region, the metropolitan areas; in the Northeastern, state' capital cities and regional hinterlands, such as Patos-PB or Petrolina-PE and, the extremely poor municipalities in the interior.

When the UVlexp is spatialized in order to demonstrate the concentration of vulnerability and exposure, compared to the hydrometeorological disasters observed between 2005-2015, a strong correlation between vulnerability hotspots ${ }^{7}$ (Figure $5 c$ ) and disaster concentration is noted (Figures 5a e 5b).

Figure 5 shows high UVlexp patches and high concentration of disasters are observed in the area close to the Atlantic Ocean. Tabular data assessment shows 399 municipalities in the Brazilian Coastal Zone (IBGE, 2010), with 13 out of 27 state capitals with approximately 50 million people (IBGE, 2010). Although these represent only $10 \%$ of the total disaster occurrences during the period assessed, $25 \%$ of the Brazilian population live in those areas where, between 2005 and 2015, 23 deaths and 260,000 people affected (homeless, displaced or injured) by river floods were recorded; and 529 people were killed and another 580,000 were affected by landslides.

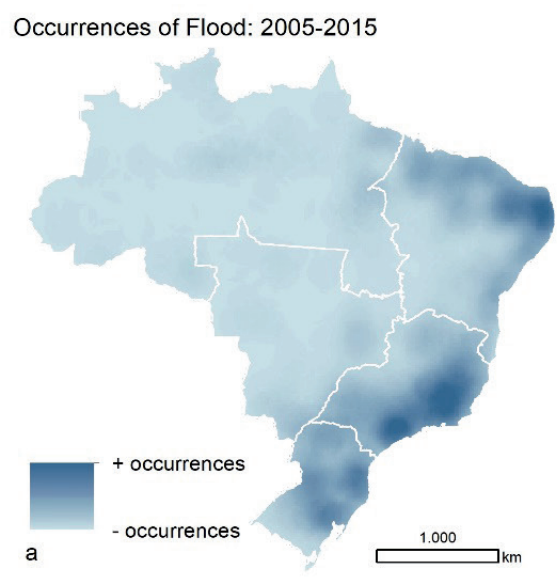

Occurrences of Landslides: 2005-2015

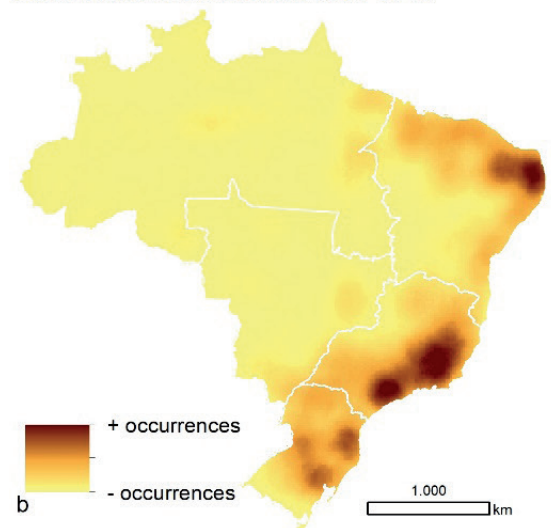

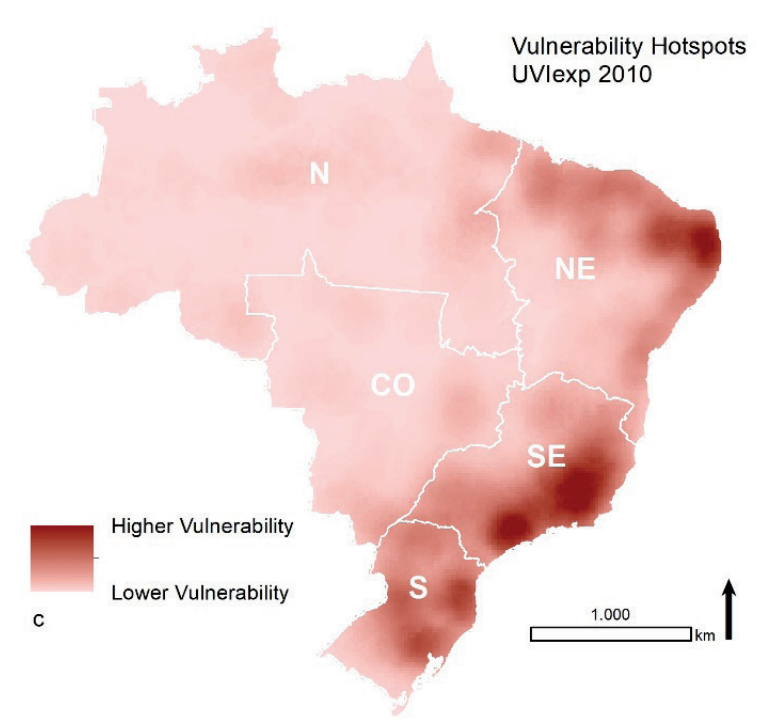
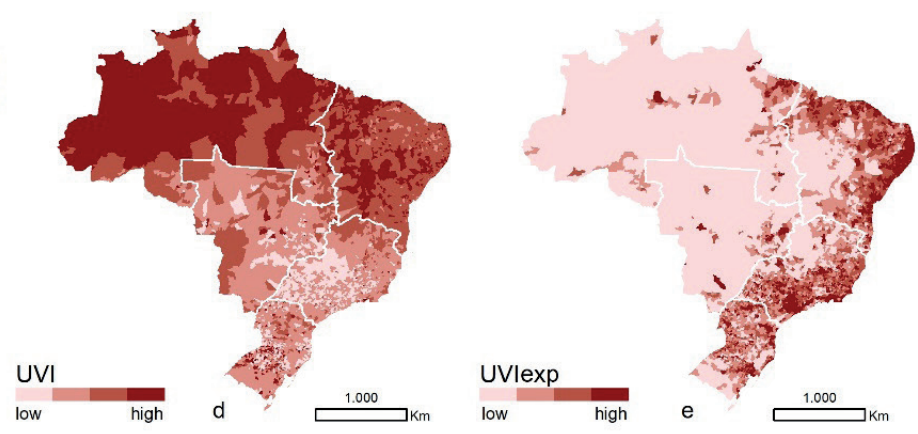

Figure 5 | Occurrence density of (a) surface water floods, floods and flash floods, and (b) landslides and mudslides; (c) vulnerability hotspots; (d) UVI and (e) UVlexp. Sources: CENAD (2018), IBGE and IDSUS (2010), IDEB (2011). 
In relation to the Southern and Southeastern regions (Figure 5), which concentrate 27 and 80 million inhabitants, respectively, it is possible to observe that exposure is an important factor when analyzing disaster impacts in the country, especially when large patches of floods and landslides are concentrated in these two regions. The Southeastern region reported the highest death toll from landslides (1,724 dead and 192 people missing), and the second highest death toll from floods (116 dead and 30 people missing). The Southern region reported 177 deaths and 36 people missing from landslides, and 93 deaths and 10 people missing from floods. In total, the Southeastern and Southern regions combined accounted for approximately $65 \%$ of those affected by landslides and $37 \%$ of those affected by floods (Table 1 ).

Table 1 | Percentage of people affected by hydrometeorological disasters between 2005 and 2015.

\begin{tabular}{r|r|r|r|r|r|r|r|r}
\hline \\
\cline { 2 - 8 }
\end{tabular}

Source: prepared by the authors.

The Northeastern region, highlighted both as a vulnerability hotspot and in the occurrence of disasters (Figure $5 \mathrm{a}, \mathrm{b}$ and c) presents the second largest concentration of people affected by both types of disasters, with values that are very close to those in the Southeastern, in both cases. There, 76 deaths and 25 people missing were reported due to floods and 123 deaths and 88 people missing were reported due to landslides; 525,000 people were left homeless or displaced by landslides and more than 300,000 due to floods during the period assessed.

The outcomes reported for the Southeastern and Northeastern regions are corroborated by floods and landslides vulnerability outcomes, presented by Debortoli et al. (2017), which show high vulnerability to both types of disasters in these two regions, and Saito (2019) who, when presenting the number of people and households in risk areas, highlights these same three regions, with a greater concentration of people exposed in the Southeastern and Northeastern regions.

The Northern region presents the lowest number of people affected by landslides, as shown by Debortoli et al. (2017), for being a region with little declivity and low vulnerability to this type of disaster. However, the regions presents the highest number of total people affected by floods, when compared to other regions, with over 1 million people affected in the snapshot assessed, which is largely explained by Bartiko et al. (2019), which show the great magnitude of floods in the Amazon, which coincide with the abrupt floods in the period assessed herein, from 2005 to 2015, and in the highlighted area, of high IVUexp, which is more visible in Figure $5 \mathrm{e}$ in the central region of the Amazon. Finally, the Center-West region presents fewer people affected in both types of disasters. Nevertheless, numbers are in the tens of thousands, in addition to 8 deaths from floods, and 14 deaths from landslides.

In relation to Urban Vulnerability and Exposure classes, Graph 1 shows the absolute numbers of people affected, by type of disaster and by UVlexp class, based on the disaster occurrences. 
Graph 1 | Number of people affected, by UVlexp class.

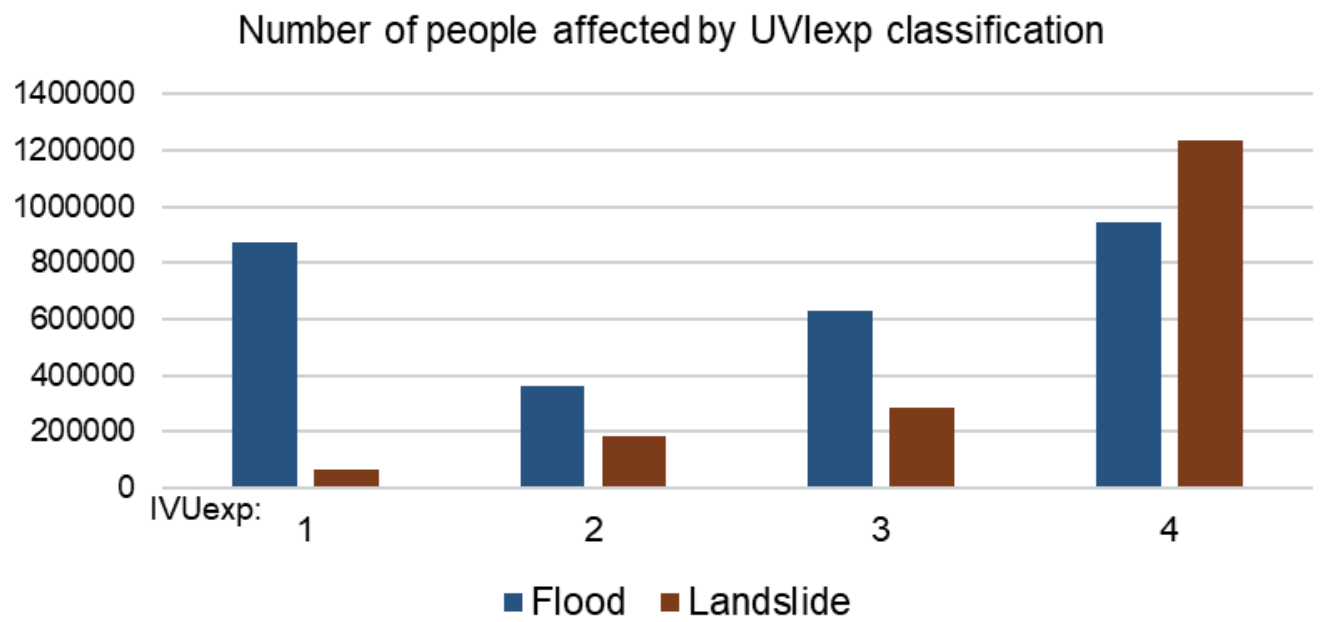

Source: Source: prepared by the authors.

The number of people affected increases as vulnerability and exposure increases, as represented by classes 1 to 4 of the UVlexp, except those affected by floods in Class 1, with less vulnerability and exposure. When data is assessed on the micro-scale, this result is explained by the large number of floods in small municipalities, $63 \%$ of them with less than 20,000 inhabitants, which confirm the analyzes by Saito et al. (2020) that the most densely populated areas are not always the most exposed, and that special attention is needed for small municipalities.

The percentages of people affected by disasters as per CENAD categories: dead and missing; sick and injured; unsheltered and displaced, are presented herein in Graphs 2 and 3, divided per UVlexp class.

\section{Graphs 2 and 3 | Percentage of people affected, per disaster category and UVlexp class}
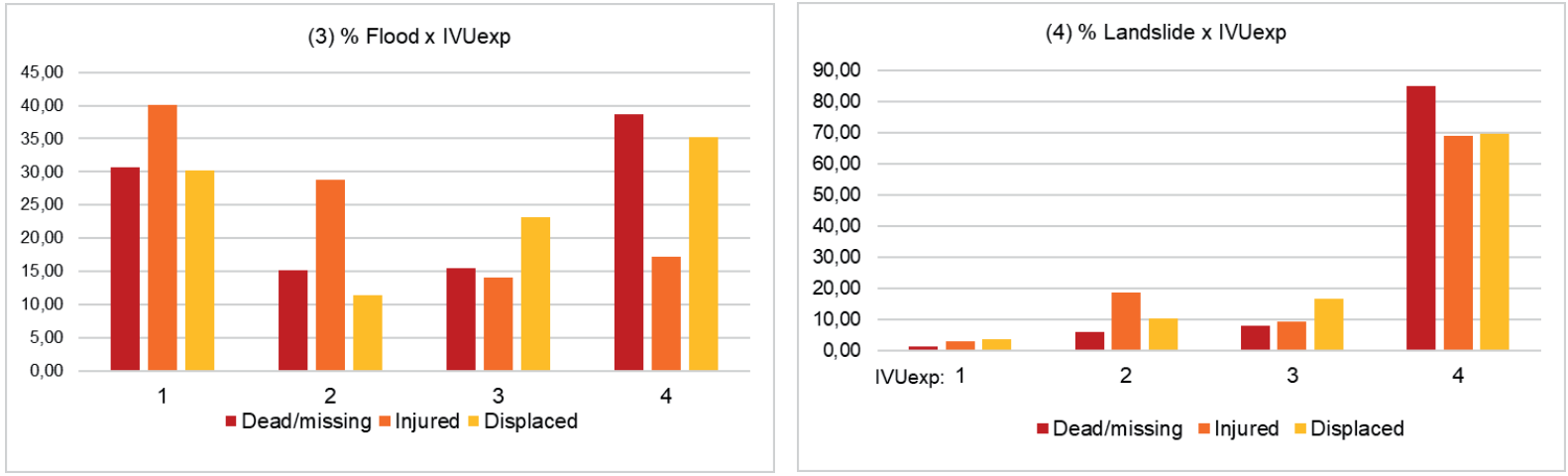

Source: Source: prepared by the authors.

Graph 2 shows that the major concentrations of dead or missing people as a result of floods, are in UVlexp classes 1 and 4 . UVlexp class 1 refers to small municipalities. UVlexp class 4 refers to informal settlements in larger cities (MARICATO, 2009), and high waterproofing rate in Brazilian cities (RASCH, 2016). Graph 3 presents a clear relationship among urban vulnerability, exposure and percentage of people affected by disasters.

The largest concentrations of people affected are in the most vulnerable municipalities, with greater exposure, which are also capital cities and metropolitan regions, according to Hummell et al. (2016). These results are coherent to those by Saito et al. on areas of risk (2019 2020), except for the Northern region, mainly due to the low population density. This finding is in line with IPCC projections (2019) in the Climate Change and Land Special Report, which point at higher occurrence of landslide disasters in 
cities with "poor planning", that is, with high concentration of informal settlements, slums and housing units (MARICATO, 2009).

Finally, it is determined that an index where 4 of 8 variables refer to urban infrastructure shows adherence to disasters that have been observed, and which are directly related to environmental sanitation services.

\subsection{FUTURE CLIMATE SCENARIOS}

When vulnerabilities to floods and landslides are plotted using the Debortoli et al indexes (2017), the high risk areas (Figure 6 -Baseline in blue and yellow) are the Southeastern and Southern regions, northern Northeastern region, east Amazon and the mouth of the Amazon river (which is a permanent flooded area), as well as the eastern coastal zone in the Northeastern region. These regions are similar to those mapped by Debortoli et. al. (2017), which, in the Baseline, show that the most vulnerable areas to sudden floods are the Southern and Southeastern regions of Brazil, as well as the east part of the states in the Northeast. The Amazon has some areas that are most at risk for flooding, but the municipalities in this area have low population density and exposure is not high. These regions are qualitatively similar to the areas affected by these hydrometeorological hazards as indicated by CEPED (2013).

Regarding landslides (Figure 6, yellow), the most vulnerable locations in the Baseline, according to Debortoli et al (2017) and the CEPED Atlas (2013) coincide with municipalities that are usually linked to areas affected by extreme rainfall, like: the metropolitan regions of São Paulo and Santos, São Paulo's northern coast, the borders between São Paulo and Rio de Janeiro (Cunha, São José do Barreiro and Angra dos Reis); the region of Serra da Mantiqueira, Southern and Southeastern regions of Minas Gerais, the mountainous region of Rio de Janeiro and the region near Serra do Caparão. When records of floods are associated with climate indicators of extreme current rain, they suggest an increase in the vulnerability of urban areas in the Southern, Southeastern and parts of the Northeastern regions, particularly in the Atlantic Forest, the most populated biome.
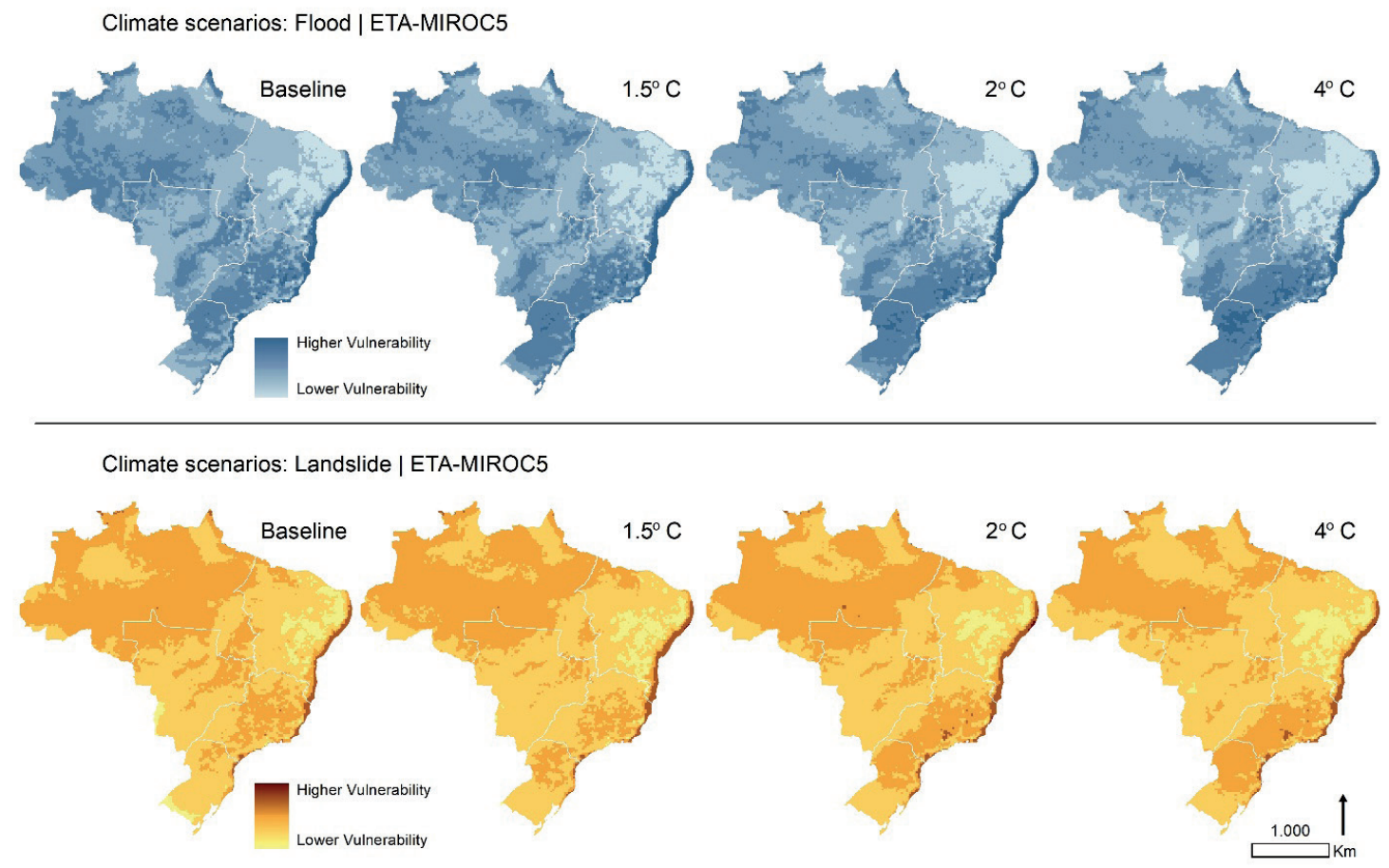

Figure 6 | Climate extremes compound indexes. 
Projections for various warming levels (Figure 6, in blue) show that, due to the increase in intense rainfall in the Southeastern and Southern regions, projected by models, in the future the risk of floods may increase in these regions, as well as in the coastal zone in the states of the Northeast and some areas in the Amazon. The risk of increased disaster occurrences is greater when global warming exceeds $2^{\circ} \mathrm{C}$.

In the semiarid region, the risk of Hydrometeorological disasters is lower due to projections that show a decrease in total and intense rainfall, with warming above $2^{\circ} \mathrm{C}$. In the RCP 4.5 scenario, the central region of Brazil (the Pantanal) and the semiarid region in the Northeast have shown a reduction in vulnerability. On the other hand, the Southern and Southeastern regions, as well as the eastern coastal zone in the Northeast, have shown a significant increase in the risk of hydrometeorological hazards.

The same association for landslides (Figure 6, in yellow) shows that, mostly for SWL 20 and 40 scenarios, and for RCP 4.5, extreme rainfall that cause landslides are expected to further increase in the Souther and Southeastern regions, and in some coastal areas in the Northeast. This increases the risk of landslides in the states of Santa Catarina, Rio Grande do Sul, eastern Paraná, the northeastern coast of São Paulo and the region of Serra da Mantiqueira, particularly the region close to the border with the state of Minas Gerais. These places have been characterized as likely spots for recurrent landslide disasters at present, and show strong evidence of intensification in the future. On the other hand, vulnerability index drops in the country's central region due to a declining trend in extreme rainfall, particularly in the Center-West states and in the semiarid region in the Northeast.

According to the present index analysis, some areas have been stricken by disasters; thus, vulnerability in those areas may become more frequent and intense in the future due to strong evidence that extreme rainfall events will increase. Our results and those by Debortoli et. al. (2017) support the AR5 (IPCC, 2014) results, that extreme rainfall events causing disasters are expected to increase in the Southern and Southeastern regions of Brazil, mainly in the Coastal Zone, where a large number of capital cities is located, with much of the country's population.

It must be noted that, in the coastal zone, disaster risks may be aggravated by events associate with sea level rise, such as storm tides, phenomena that may be likewise influenced by climate change, mainly in the area comprising mouth of the Amazon river to the Maranhão coast, along the entire south and southeast coast and in the northeastern capitals, as per Almeida et. al. (2016), who, when also measuring municipalities response and adaptation capacities to this impact, shows that the Northern and Northeastern regions concentrate the least prepared municipalities.

\section{FINAL CONSIDERATIONS}

The high concentration of observed disasters and the vulnerability and exposure hotspots in the Northeastern region are a concern because of the poor regional urban infrastructure and projections for increased extreme rainfall that cause floods. Even with better urban infrastructure, the high population density and the large number of precarious settlements in the Southern and Southeastern regions, coupled with the same forecast of increased extreme rainfall in the future, also trigger a warning for an increase in hydrometeorological disasters. The Center-West region, despite presenting lower occurrences, shows numbers in the tens of thousands. In the Northern region, UVlexp failed and showed no spatial correlation with floods that affected one million people in the 10 years of data assessed, mostly because of low exposure.

Among the Brazilian Government's proposals to reduce the risk of disasters, the creation of CEMADEN, liaison between CPRM and IBGE for the mapping and classification of risk areas, and the proposed civil defense chain have been performed. However, the key to reduce the risk of disasters in the country also lies in urban development (NOGUEIRA et al., 2014). 
The main instrument for regulating, managing, planning and improving Brazilian urban conditions is the City Statute (LF 10.257/2001), which provides for planning. The Ministry of Cities (now extinct) was responsible for integrating urban policies among the 3 levels of Government (2003 - 2019), in addition to supporting land regularization, housing provision, sanitation and mobility, intergovernmental integration, which is extremely important for small municipalities that depend on technical support from the Government (PEREZ et al., 2017).

Discontinuity of programs such as Risk Reduction and Eradication within the Urbanization, Regularization and Integration of Precarious Settlements Program (or simply Urbanization of Favelas), which provided for the allocation of federal resources for urbanization works and disaster risk reduction, creation permeable green areas, or the Papel Passado program, which provided technical training to implement land regularization, weakens urban adaptation to climate change. The use of instruments of the Reurb Law (Federal Law No. 13,465/2017), which allow for adapting housing to the necessary legislation to ensure the social and environmental security of families at risk, is also weakened without the Ministry of Cities. The Master Plan is urban policy's main municipal instrument, and it is pivotal for adaptation to climate change, however, besides the fact that $75 \%$ of Brazilian cities being exempt from the obligation to elaborate it, many cities have legislation that has been approved without spatial planning (ALMEIDA et al, 2017).

Housing provision for AGSN families in risk to be relocated, marked in recent years by the Minha Casa Minha Vida (My House, My Life) program, not only is now estinguished but, when in operation, amplified the periphery of low-income communities (ROLNIK, 2015).

Lastly, the new Brazilian Basic Sanitation Law (Federal Law No. 14,026/2020) provides for the management of water and sewage services, without considering climate change or the increase of rainfall extremes that cause hydrometeorological disasters. Therefore, it does not specify rules for the resizing of rainwater management systems, or the use of green or blue infrastructure in order to increase urban resilience and mitigate emissions.

Inter-institutional and inter-level liaisons are an essential condition for reduction of disaster risks. The lack of an urban policy that reaches precarious settlements, universal environmental sanitation and sustainable implementation of green and blue infrastructures means that the role of monitoring entities of risk and civil defense will continue to fail in prevention.

\section{REFERENCES}

ALMEIDA, L. Q.; WELLE, T.; BIRKMAN, J. Disaster risk indicators in Brazil: a proposal based on the world risk index. International Journal of Disaster Risk Reduction, n. 17, p. 251-272, 2016. http://dx.doi.org/10.1016/j. ijdrr.2016.04.007

ALMEIDA, G. M. et al. A política nacional de regularização fundiária: capacidades institucionais dos municípios na implementação do Programa Federal Papel Passado e suas implicações na gestão do território. In: XVII ENCONTRO NACIONAL DA ASSOCIAÇÃO NACIONAL DE PÓS-GRADUAÇÃO E PESQUISA EM PLANEJAMENTO URBANO E REGIONAL - ENANPUR, XVII, 2017. São Paulo, 2017.

ALVALÁ, R. et al. Mapping characteristics of at-risk population to disasters in the context of Brazilian early warning system. International Journal of Disaster Risk Reduction, v. 41, 2019. 101326.

BARCELLOS, C.; HACON, S. Mudanças climáticas e ambientais e as doenças infecciosas: cenários e incertezas para o Brasil. Epidemiologia e Serviços de Saúde, v. 18, n. 3, p. 285-304, Brasília, 2009.

BARTIKO, D. et al. Spatial and seasonal patterns of flood change across Brazil. Hydrological Sciences Journal, v. 64, n. 9, p. 1071-1079, 2019. DOI: 10.1080/02626667.2019.1619081

BRASIL. Ministério das Cidades. Regularização fundiária sustentável: conceitos e diretrizes. Brasília, 2007. 
BURIAN, S.; EDWARDS, F. Historical Perspectives of Urban Drainage. Ninth International Conference on Urban Drainage. 2012. https://doi.org/10.1061/40644(2002)284

CALDERIA, T. Cidades de muros: crime e segregação na metrópole. EdUSP: São Paulo, 2000.

CAMPOS, J. N. B.; STUDART, T. M. C. Drought and water policies in Northeast Brazil: backgrounds and rationale. Water policy, v.10, p. 425-38, 2008.

CENAD. Registro de ocorrência de desastres naturais 2005-2015. Dados gentilmente cedidos pela Coordenação de Análise de Risco do Centro Nacional de Gerenciamento de Riscos e Desastres, 2018.

CEPED. Atlas Brasileiro de Desastres Naturais On-line. 2020.

$\mathrm{CHOU}, \mathrm{S}$. et al. Assessment of Climate Change over South America under RCP 4.5 and 8.5 Downscaling Scenarios. American Journal of Climate Change, v. 3, p. 512-527, 2014.

DEBORTOLI, N. et al. An index of Brazil's vulnerability to expected increases in natural flash flooding and landslide disaster in the context of climate change. Natural hazard, v. 8, n. 2, 2017.

DIAS, M. C. A. et al. Estimation of exposed population to landslides and floods risk areas in Brazil, on an intraurban scale. International Journal of Disaster Risk Reduction, v. 31, Oct. 2018.

DUNN, R. J. H. et al. Development of an updated global land in situ-based data set of temperature and precipitation extremes: HadEX3. Journal of Geophysical Research: Atmospheres, v. 125, 2020 e2019JD032263. https://doi. org/10.1029/2019JD032263

FONSECA, P. A. M. Influência de variáveis hidroclimáticas na ocorrência de diarreias em menores de $\mathbf{5}$ anos na Amazônia ocidental. Manaus: [s.n.], 2018.

FREITAS, C. M. et al. Desastres naturais e saúde: uma análise da situação do Brasil. Ciência \& Saúde Coletiva, v. 19, n. 9, p. 3645-3656, 2014

HACON, S. S.; OLIVEIRA, B. F. A.; SILVEIRA, I. Climate Change Risks in Brazil: a review of the health sector impacts of $4^{\circ} \mathrm{C}$ or more temperature rise. NOBRE, C. A.; MARENGO, J. A.; SOARES, W. R. (Org.). Impacts of $4^{\circ} \mathrm{C}$ or more Temperature Risk. UK: Springer, 2018.

HARDOY, J.; PANDIELLA, G. Urban poverty and vulnerability to climate change in Latin America. Environment and Urbanization, v. 21, n. 1, p. 203-224, 2009.

HUMMELL, B.; CUTTER, S.; EMRICH, C. Social vulnerability to natural hazards in Brazil. International Journal of Disaster Risk Science, v. 7, n. 2, 2016. doi: 10.1007/s13753-016-0090-9.

IBGE. Censo demográfico 2010. Disponível em: <https://censo2010.ibge.gov.br/>. Acesso em: ago. 2020.

IBGE. Pesquisa Nacional de Saneamento Básico. 2017. Disponível em: <https://www.ibge.gov.br/estatisticas/ multidominio/meio-ambiente/9073-pesquisa-nacional-de-saneamento-basico.html?=\&t=o-que-e>. Acesso em: ago. 2020.

IBGE. Pesquisa de Informações Básicas Municipais: Munic 2013. Disponível em: <https://www.ibge.gov.br/ estatisticas/sociais/saude/10586-pesquisa-de-informacoes-basicas-municipais.html?=\&t=o-que-e>. Acesso em: ago. 2020.

IDEB. Índice de Desenvolvimento da Educação Básica. 2011. Disponível em:<http://ideb.inep.gov.br/resultado/> Acesso em: ago. 2020.

IDSUS. Índice de Desempenho do Sistema Único de Saúde. 2010. Disponível em: <http://idsus.saude.gov.br/>. Acesso em: ago. 2020.

IPCC. Climate Change 2014: impacts, adaptation, and vulnerability. Contribution of Working Group II to the Fifth Assessment Report of the Intergovernmental Panel of Climate Change. BARROS, V. R. et al. (Ed.). Cambridge, UK and New York, NY, USA: Cambridge University Press, 2014. 
IPCC. Special Report: climate change and land. Cambridge, UK and New York, NY, USA: Cambridge University Press, 2019.

IPEA. Índice de Vulnerabilidade Social. 2015. Disponível em: <http://ivs.ipea.gov.br>.

KITA, S. M. Urban vulnerability, disaster risk reduction and resettlement in Mzuzu city, Malawi. International Journal of Disaster Risk Reduction, v. 22, 2017.

KOKS, E. E. et al. Combining hazard, exposure and social vulnerability to provide lessons for flood risk management. Environmental Science \& Policy, n. 47, p. 45-52, 2015.

LITRE, G.; BURSZTYN, M. Percepções e adaptação aos riscos climáticos e socioeconômicos na pecuária familiar do bioma Pampa. Ambiente \& Sociedade, v. XVIII, n. 3, p. 55-80, 2015.

MARENGO, J. O futuro do clima no Brasil. Revista USP, n. 103, p. 25-32. São Paulo, 2014.

MARENGO, J. A.; ESPINOZA, J. C. Extreme seasonal droughts and floods in Amazonia: causes, trends and impacts. Int. J. Climatol. v. 36, p. 1033-1050, 2016. doi: 10.1002/joc.4420

MARENGO, J. A. et al. Changes in climate and land use over the amazon region: current and future variability and trends. Front. Earth Sci. v. 6, p. 228, 2018. doi: 10.3389/feart. 2018.00228

MARENGO, J. A. et al. Trends in extreme rainfall and hydrogeometeorological disasters in the Metropolitan Area of São Paulo: a review. Ann. N.Y. Acad. Sci. p. 1-16, 2020a. doi: 10.1111/nyas.14307

MARENGO, J. A. et al. Changing Trends in Rainfall Extremes in the Metropolitan Area of São Paulo: causes and impacts. Front. Clim. v. 2, n. 3, 2020b. doi: 10.3389/fclim.2020.00003

MARENGO, J. A. et al. A seca e a crise hídrica de 2014-2015 em São Paulo. Revista USP. São Paulo, n. 106, p. 31-44 julho/agosto/setembro 2015.

MARENGO, J.; ALVES, L. M. The 2011 intense rainfall and floods in Rio de Janeiro. In: State of the Climate in 2011. Bulletin of American Meteorological Society, 93, p. S175-S177, 2012.

MARENGO, J. et al. Recent Extremes of Drought and Flooding in Amazonia: vulnerabilities and human adaptation. American Journal of Climate Change, v. 02, n. 02, p. 87-96, $2013 a$.

MARICATO, E. Conhecer para resolver a cidade ilegal. CASTROLA, L. (Org.) Urbanização Brasileira. Ed. C/Arte: São Paulo, 2003.

. Metrópole, legislação e desigualdade. Estudos Avançados, v. 17, n. 48, p. 151, 2003b.

Informalidade Urbana no Brasil: a lógica da cidade fraturada. In: A cidade de São Paulo, relações internacionais e gestão pública. WANDERLEY, L. E.; RAICHELIS, R. (Org). Ed Educ, 2009.

The future of global peripheries cities. Latin America Perspective, v. 44, n. 2, p. 18-37, 2017. doi:10.1177/0094582X16685174

MIKOSZ, L. Sendai Framework Indicators for Disaster Risk Reduction in Brazil: initial conditions, feasibility analysis, and understanding the risk. National Graduate Institute for Policy Studies (GRIPS): Tokyo, Japan, 2017.

NOGUeIRA, F.; OLIVEIRA, V.; CANIL, K. Políticas Públicas Regionais para Gestão de Riscos: o processo de implementação no ABC, SP. Ambiente \& Sociedade. São Paulo, v. XVII, n. 4, p. 177-194, out.-dez. 2014.

OJIMA, R. Urbanização, dinâmica migratória e sustentabilidade no semiárido nordestino: o papel das cidades no processo de adaptação ambiental. Caderno Metrópoles, v. 15, n. 29, p. 35-54. São Paulo, 2013.

PBMC. Primeiro Relatório de Avaliação Nacional: impactos, vulnerabilidade e adaptação. v. 2. Painel Brasileiro de Mudanças Climáticas. Governo Federal, Brasília, 2016.

PEREZ, L. P. et al. Spatial data in the Global South: a case study of alternative land management tools for cities 
with limited resources. In: 2017 IEEE - GHTC: California, 2017.

PNUD. Atlas Brasileiro do Desenvolvimento Humano nos Municípios Brasileiros. Disponível em: <http:// atlasbrasil.org.br/2013/>. Acesso em: ago. 19.

RASCH, R. Income Inequity and Urban Vulnerability to Flood Hazard in Brazil. Social Science Quarterly, v. 98, n. 1, p. 299-325, 2017.

ROLNIK, R. O Programa Minha Casa Minha Vida nas regiões metropolitanas de São Paulo e Campinas: aspectos socioespaciais e segregação. Cad. Metrop. São Paulo, v. 17, n. 33, p. 127-154, May 2015.

RUFAT, S. et al. Social vulnerability to floods: review of case studies and implications for measurement. International Journal of Disaster Risk Reduction, v. 14, p. 4, 2015.

SAITO, S. M. et al. Disaster risk areas in Brazil: outcomes from an intra-urban scale analysis. International Journal of Disaster Resilience in the Built Environment. https://doi.org/10.1108/IJDRBE-01-2020-0008

SAITO, S. M. et al. População urbana exposta aos riscos de deslizamentos, inundações e enxurradas no Brasil. Sociedade \& Natureza, v. 31, 29 nov. 2019.

SÃO PAULO (Estado). Relatório de Defesa Civil. 2019. Disponível em: <https://www.saopaulo.sp.gov.br/ spnoticias/defesa-civil-do-estado-atualiza-situacao-na-baixada-santista/>. Acesso em: ago. 2020.

SILVA, D. X.; BARCELLOS, C.; BACURI, R. Vulnerabilidade e efeitos das mudanças climáticas na saúde pública em Manaus. Project report on Guidance for Conducting Assessments of Health Vulnerability and Public Health and Health Care Interventions to Address Climate Change, funded by the Pan-American Health Organisation, 2010.

TOMINAGA, L.; SANTORO, J.; AMARAL, R. Desastres naturais: conhecer para prevenir. Instituto Geológico: São Paulo, 2009.

TRAVASSOS, L.; TORRES, P.; GIULIO, G. et al. Why do extreme events still kill in the São Paulo Macro Metropolis Region? Chronicle of a death foretold in the global south. International Journal of Urban Sustainable Development. 2020. DOI:10.1080/19463138.2020.1762197

TUCCI, C. E. M. Águas urbanas. Revista Estudos Avançados, v. 22, n. 63, São Paulo, 2008.

UFMG. Podcast da UFMG: as chuvas de BH, 2020. Disponível em: <https://ufmg.br/comunicacao/noticias/ planejamento-equivocado-transforma-chuva-em-inimiga>. Acesso em: ago. 2020.

UNISDR. Economic losses, poverty \& disasters: 1998-2017. Author(s) WALLEMACQ, P.; ROWENA, H. 2018.

UNDRR. Global Assessment Report on Disaster Risk Reduction. Geneva, Switzerland. United Nations Office for Disaster Risk Reduction (UNDRR). 2019. eISBN: 978-92-1-004180-5 